\title{
PENGARUH KUALITAS PELAYANAN, KEPERCAYAAN, DAN NILAI NASABAH TERHADAP KEPUASAN NASABAH PT. BANK MANDIRI (PERSERO) TBK. CABANG PADANG
}

\author{
Novreza, Aminar Sutra Dewi \\ Sekolah Tinggi Ilmu Ekonomi KBP \\ aminarsutradewi@akbpstie.ac.id
}

\begin{abstract}
The purpose of this research is to know and analyze the influence dimension of service quality, trust, and customer value to customer satisfaction of PT. Bank Mandiri (Persero) Tbk. Branch Padang Olo. The sampling technique used is random sampling, while the number of samples used for the analysis is 100 people. Data analysis techniques used to test the hypothesis is multiple linear regression. In this study there are seven independent variables, namely physical evidence, empathy, reliability, responsiveness, assurance, trust, and customer value. Variables that have a significant influence on customer satisfaction PT. Bank Mandiri (Persero) Tbk. Padang Olo Branch is trust, and customer value. While the value of determination coefficient in this study was found at 0.509 or equal to 50.9\%. These results show that customer satisfaction at PT. Bank Mandiri (Persero) Padang Branch behind Olo which can be explained by the physical evidence, empathy, reliability, responsiveness, assurance, trust, and customer value of $50.9 \%$, while the remain ing $49.1 \%$ allegedly explained by other factors not examined in this study, such as bank image, and service marketing mix. Based on the results of multiple linear regression analysis, it was found that the variables of physical evidence, empathy, reliability, responsiveness, assurance, trust, and customer value positively affect customer satisfaction at PT. Bank Mandiri (Persero) Padang Branch behind Olo. This research provides practical recommendations for the management of T. Bank Mandiri (Persero) Padang Branch behind Olo to continuously strive to increase trust, and value of customers in the future. This is due to trust, and the value of customers has a significant effect on customer satisfaction at the PT. Bank Mandiri (Persero) Padang Branch behind Olo
\end{abstract}

Keywords: Dimension of Service Quality, Trustworthiness, Customer Value, and Satisfaction

\section{PENDAHULUAN}

Dengan meningkatnya persaingan dan permintaan pasar, maka perusahaan harus mampu menerapkan strategi dan kebijakan yang tepat agar dapat menciptakan kepuasan nasabahnya dan mengatasi persaingan dengan perusahaan lain. Sehingga dapat mempertahankan keberlangsungan usahanya. Bank yang juga 
menghadapi persaingan yang ketat dalam industry perbankan adalah Bank Mandiri (Persero) Tbk. Cabang Padang Belakang Olo.

Bank Mandiri (Persero) Tbk. Cabang Padang Belakang Olo merupakan salah satu bank yang beroperasi di Indonesia pada saat ini dan merupakan salah satu bank terbesar milik pemerintah. Bank mandiri berasal dari merger empat buah bank pada tahun 1999. Bank Mand iri merupakan bank umum yang berstatus perusahaan publik, yang berorientasi kepada pasar dan pembangunan nasional, yang secara terus menerus membina hubungan yang baik dan saling menguntungkan dengan nasabah dan mitra usaha.

Dalam mengembangkan segmen pasar Bank Mandiri senantiasa menghadirkan produk dan layanan yang berkualitas bagi jutaan nasabah dan calon nasabah. Pengembangan yang dilakukan dengan cara menggunakan keunggulan pengalaman dan keahlian, serta mengoptimalkan potensi pemasaran pada segmen yang dituju. Untuk menghadapi persaingan di industri ini mengharuskan Bank Mandiri memberikan kualitas jasa yang memiliki keunggulan bersaing terhadap bank - bank umum lainnya.

Bank Mandiri terus memasarkan produk simpanan masyarakat berupa giro, deposito,dan tabungan melalui para banking account manager, relationship manager, tim pemasaran di cabang maupun dilapangan, serta customer service dikantor-kantor. Salah satu produk tabungan yang dimilikiBank Mandiri adalah Mandiri Tabungan, Mandiri Tabungan Bisnis, Mandiri Tabungan Rencana, Mandiri Tabungan Investor, Mandiri Tabungan Haji dan Umroh, Mandiri Tabungan Valas, Mandiri Tabunganku, dan Mandiri Tabungan TKI.

Produk tabungan ini merupakan produk yang menjadi primadona karena merupakansumber dana yang lebih murah dimanabiaya dana yang dikeluarkan lebih rendahhal ini disebabkan karena tingkat bunga yang diberikan tidak setinggi simpanan berjangka. Dengan kondisi tersebut Bank Mandiri berusaha untuk melakukan penghimpunan dana tabungan masyarakat sebesar-besarnya dengan upaya pemberian layanan yang prima kepada nasabah dan memberikan fitur-fitur produk tabungan yang berkualitas, seperti akses layanan 24 jam melaluiATM, internet banking, SMS Banking,phone banking dan mobile banking dengan demikian memiliki kebebasanbertransaksi kapan saja dan dimana sajatanpa perlu harus datang ke bank.

Fenomena yang ditemui di Bank Mandiri Cabang Padang Belakang Olo yang berkaitan dengan kepuasan nasabah yaitu adanya penutupan rekening Polisi Daerah (Polda) Sumatera Barat ke Bank Bri \pm 1500 rekening tabungan yang didukung oleh keputusan dari Kantor Pusat Mandiri sehinga membuat tabungan Mandiri Belakang Olo sangat menurun ditambah lagi dengan aturan atau kebijakankalau tabungan haji Bank Mandiri juga harus di tutup dan dipindahkan ke Bank Syariah Mandiri dimana Bank Syariah Mandiri merupakan anak perusahaan Bank Mandiri yang berbeda secara sistem dan laporan keuangannya, pada akhir tahun 2015 dibulan nopember.

Bank Mandiri Belakang Olo melakukan renovasi gedung yang dipindahkan ke gedung sementara yang terletak dibelakang kantor Bank Mandiri Belakang Olo sekarang, dimana digedung sementara ini gedungnya lebih kecil dan ruang parkir semakin sempit biasanya kapasitas mobil bisa 15 unit semenjak 
renovasi mobil parkir hanya bisa 3 unit saja karena lahan yang dipakai untuk renovasi gedung baru, dengan park ir yang tidak memadai membuat nasabah malas datang ke Bank Mandiri Belakang Olo.

Karena merasa tidak nyaman untuk bertransaksi selain itu nasabah tidak puas dikarenakan karyawan Bank Mandiri Belakang Olo tidak cepat tanggap dalam menangani keluhan nasabah membutuhkan waktu yang lama untuk bertransaksi diteller dan custumer service masih lambat untuk melakukan pencairan dana harus melewati standar operasional yang cukup lama kalau nasabah tidak membawa dokumen yang lengkap misalnya penarikan tanpa ATM.

\section{Rumusan Masalah}

1. Bagaimana pengaruh tangible terhadap kepuasan nasabah tabungan pada Bank Mandiri Cabang Padang?

2. Bagaimana pengaruh empathy terhadap kepuasan nasabah tabungan pada Bank Mandiri Cabang Padang?

3. Bagaimana pengaruh reliability terhadap kepuasan nasabah tabungan pada Bank Mandiri Cabang Padang?

4. Bagaimana pengaruh responsiveness terhadap kepuasan nasabah tabungan pada Bank Mandiri Cabang Padang?

5. Bagaimana pengaruh assurance terhadap kepuasan nasabah tabungan pada Bank Mandiri Cabang Padang?

6. Bagaimanakah pengaruh kepercayaan terhadap kepuasan nasabah tabungan pada Bank Mandiri Cabang Padang Belakang Olo ?

7. Bagaimanakah pengaruh nilai nasabah terhadap kepuasan nasabah tabungan pada Bank Mandiri Cabang Padang Belakang Olo ?

\section{Tujuan Penelitian}

1. Pengaruh tangible terhadap kepuasan nasabah tabungan pada Bank Mandiri Cabang Padang Belakang Olo.

2. Pengaruh empathy terhadap kepuasan nasabah tabungan pada Bank Mandiri Cabang Padang Belakang Olo.

3. Pengaruh reliability terhadap kepuasan nasabah tabunganpada Bank Mandiri Cabang Padang Belakang Olo.

4. Pengaruh responsiveness terhadap kepuasan nasabah tabungan pada Bank Mandiri Cabang Padang Belakang Olo.

5. Pengaruh assurance terhadap kepuasan nasabah tabunganpada Bank Mandiri Cabang Padang Belakang Olo.

6. Pengaruh kepercayaanterhadap kepuasan nasabah tabungan pada Bank Mandiri Cabang Padang Belakang Olo.

7. Pengaruh nilai nasabah terhadap kepuasan nasabah tabungan pada Bank Mandiri Cabang Padang Belakang Olo.

\section{LANDASAN TEORI}

Kepuasan Pelanggan

\section{Pengertian Kepuasan}

Menurut Tjiptono (2005) kepuasan pelanggan adalah keseluruhan sikap yang ditunjukkan konsumen atas barang dan jasa setelah mereka memperoleh dan menggunakannya. Sedangkan Rambat Lupiyoadi (2001) kepuasan pelanggan merupakan suatu tingkatan dimana kebutuhan, keinginan, dan harapan dari 
pelanggan akan dapat terpenuhi atau terlampaui melalui suatu transaksi yang akan mengakibatkan terjadinya pembelian ulang.

\section{Kualitas Pelayanan}

\section{Pengertian Kualitas Pelayanan}

Menurut Goetsch Davis dalam Zulian Yamit (2002) 'Kualitas merupakan suatu kondisi dinamis yang berhubungan dengan produk, jasa, manusia, proses dan lingkungan yang memenuhi atau melebihi harapan".

Menurut American Society for Quality Control (Philip Kotler, 2007) "kualitas jasa adalah keseluruhan ciri serta sifat dari suatu produk atau pelayanan yang berpengaruh pada kemampuannya untuk memuaskan kebutuhan yang dinyatakan atau yang tersirat".

\section{Kepercayaan}

\section{Pengertian Kepercayaan}

Kepercayaan adalah keyakinan bahwa seseorang akan menemukan apa yang diinginkan pada mitra pertukaran. Kepercayaan melibatkan kesediaan seseorang untuk bertingkah laku tertentu karena keyakinan bahwa mitranya akan memberikan apa yang ia harapkan dan suatu harapan yang dimiliki seseorang bahwa kata janji atau pernyataan orang lain dapat dipercaya (Barnes, 2003).

\section{Nilai Nasabah}

\section{Pengertian Nilai Nasabah}

Dalam Fandy Tjiptono (2011: 15) menekankan bahwa pemasaran berkaitan erat dengan upaya menciptakan dan memberikan nilai (value) kepada pelanggan. Secara sederhana, nilai pelanggan (costumer value) ditentukan oleh selisih antara manfaat total dan biaya total bagi pelanggan

\section{Hipotesis}

Hipotesis 1 Diduga tangible berpengaruh positif dan signifikan terhadap kepuasan nasabah tabungan pada Bank Mandiri Cabang Padang Belakang Olo.

Hipotesis 2 Diduga empathy berpengaruh positif dan signifikan terhadap kepuasan nasabah tabungan pada Bank Mandiri Cabang Padang Belakang Olo.

Hipotesis 3 Diduga reliability berpengaruh positif dan signifikan terhadap kepuasan nasabah tabungan pada Bank Mandiri Cabang Padang Belakang Olo.

Hipotesis 4 Diduga resposiveness berpengaruh positif dan signifikan terhadap kepuasan nasabah tabungan pada Bank Mandiri Cabang Padang Belakang Olo.

Hipotesis 5 Diduga assurance berpengaruh positif dan signifikan terhadap kepuasan nasabah tabungan pada Bank Mandiri Cabang Padang Belakang Olo.

Hipotesis 6 Diduga kepercayaan berpengaruh positif dan signifikan terhadap kepuasan nasabah tabungan pada Bank Mandiri Cabang Padang Belakang Olo.

Hipotesis 7 Diduga nilai nasabah berpengaruh positif dan signifikan terhadap kepuasan nasabah tabungan pada Bank Mandiri Cabang Padang Belakang Olo. 


\section{METODE PENELITIAN}

\section{Populasi dan Sampel}

Dalam penelitian ini populasinya adalah seluruh nasabah yang Melakukan penyimpanan dana khususnya dana tabungan pada Bank Mandiri Cabang Padang Belakang Olo sampai dengan tahun 2016 yang berjumlah 13.197 orang.

Dalam pelaksanaan penelitian, prosedur pengambilan sampel berdasarkan teknik proportional stratified random sampling adalah pengambilan sampel dalam strata tertentu kemudian diambil secara random dengan proporsi seimbang sesuai posisi dalam populasi.Jadi besarnya sampel penelitian yang digunakan dalam penelitian ini adalah berjumlah 100 orang nasabah.

\section{Teknik Analisis Data}

\section{Analisis Regresi Linier Sederhana}

Uji regresi linear sederhana merupakan teknik statistik yang digunakan untuk menguji pengaruh variabel bebas terhadap variabel terikat (Sekaran, 2006:299). Persamaan regresi linier sederhana adalah:

$\mathrm{Y}=\mathrm{a}+\mathrm{b}_{1} \mathrm{X}_{1}+\mathrm{b}_{2} \mathrm{X}_{2}+\mathrm{b}_{3} \mathrm{X}_{3}+\mathrm{b}_{4} \mathrm{X}_{4}+\mathrm{b}_{5} \mathrm{X}_{5}+\mathrm{b}_{6} \mathrm{X}_{6}+\mathrm{b}_{7} \mathrm{X}_{7}$

dimana :

$\begin{array}{ll}\mathrm{Y} & =\text { Kepuasan nasabah } \\ \mathrm{a} & =\text { Konstanta Y. } \\ \mathrm{b} & =\text { Koefisien regresi X. } \\ \mathrm{X}_{1} & =\text { Tangible. } \\ \mathrm{X}_{2} & =\text { Empathy. } \\ \mathrm{X}_{3} & =\text { Reliability. } \\ \mathrm{X}_{4} & =\text { Resposivenees. } \\ \mathrm{X}_{5} & =\text { Assurance. } \\ \mathrm{X}_{6} & =\text { Kepercayaan } \\ \mathrm{X}_{7} & =\text { Nilai Nasabah }\end{array}$

\section{Pengujian Hipotesis}

\section{Uji T-Statistik}

Uji t dilakukan untuk menguji apakah secara terpisah variabel independen mampu menjelaskan variabel dependen secara baik. Kriteria pengujian:

1) Jika thitung $>\mathrm{t}$ tabel, maka $\mathrm{H}_{0}$ ditolak dan $\mathrm{H}_{1}$ diterima.

2) Jika thitung < t tabel, maka $\mathrm{H}_{0}$ diterima dan $\mathrm{H}_{1}$ ditolak.

3) Tingkat kepercayaan $\alpha$ untuk pengujian hipotesis adalah $95 \%$ atau $\alpha=0,05$

\section{HASIL PENELITIAN DAN PEMBAHASAN}

\section{Hasil Analisis Regresi Berganda}

\section{Analisis Regresi Berganda}

Uji regresi linear berganda merupakan teknik statistik yang digunakan untuk menguji pengaruh beberapa variabel bebas terhadap variabel terikat (Sekaran, 2006). Hasil analisis regresi linier berganda dapat diringkas pada Tabel berikut ini: 
Tabel 1

Ringkasan Hasil Analisis Regresi Linier Berganda

\begin{tabular}{|c|l|c|}
\hline $\begin{array}{c}\text { Variabel } \\
\text { Terikat }\end{array}$ & \multicolumn{1}{|c|}{ Konstanta danVariabel Bebas } & Koefisien Regresi \\
\hline \multirow{4}{*}{$\begin{array}{c}\text { Kepuasan } \\
\text { Nasabah } \\
(Y)\end{array}$} & Konstanta $(\mathrm{a})$ & 1.609 \\
\cline { 2 - 3 } & Bukti Fisik $\left(\mathrm{X}_{1}\right)$ & 0.057 \\
\cline { 2 - 3 } & Empati $\left(\mathrm{X}_{2}\right)$ & 0.085 \\
\cline { 2 - 3 } & Keandalan $\left(\mathrm{X}_{3}\right)$ & 0.119 \\
\cline { 2 - 3 } & Daya Tanggap $\left(\mathrm{X}_{4}\right)$ & 0.125 \\
\cline { 2 - 3 } & Jaminan $\left(\mathrm{X}_{5}\right)$ & 0.164 \\
\cline { 2 - 3 } & Kepercayaan $\left(\mathrm{X}_{6}\right)$ & 0.177 \\
\cline { 2 - 3 } & Nilai Nasabah $\left(\mathrm{X}_{7}\right)$ & 0.444 \\
\hline
\end{tabular}

Sumber: Olahan Data SPSS, 2017

Berdasarkan hasil analisis regresi linier berganda yang disajikan pada Tabel di atas, berikut ini dapat dikemukakan persamaan regresi linier berganda: $\mathrm{Y}=1,609+0,057 \mathrm{X}_{1}+0,085 \mathrm{X}_{2}+0,119 \mathrm{X}_{3}+0,125 \mathrm{X}_{4}+0,164 \mathrm{X}_{5}+0,177 \mathrm{X}_{6}+$ $0,444 X_{7}$

Uji F berikut:

Dari hasil olahan data dapat diketahui hasil uji F pada tabel 4.30 sebagai

Tabel 2

Hasil Uji F

ANOVA $^{\mathrm{b}}$

\begin{tabular}{|l|r|r|r|r|r|}
\hline Model & Sum of Squares & df & Mean Square & F & Sig. \\
\hline $1 \quad$ Regression & 31.212 & 7 & 4.459 & 15.658 & $.000^{\mathrm{a}}$ \\
Residual & 26.199 & 92 & .285 & & \\
Total & 57.411 & 99 & & & \\
\hline
\end{tabular}

a. Predictors: (Constant), Nilai Nasabah, Daya Tanggap, Kepercayaan, Bukti Fisik, Keandalan, Empati, Jaminan

b. Dependent Variable:

Kepuasan Nasabah

Sumber: Olahan Data SPSS 2017.

Berdasarlan tabel diatas, terlihat bahwa nilai untuk $\mathrm{F}$ statistik dalam penelitian ini menghasilkan tingkat signifikansi 0,000 karena probabilitas signifikansi jauh lebih kecil dari 0,05, maka dapat dikatakan bahwa bukti fisik ,empati, keandalan, daya tanggap, jaminan, kepercayaan, dan nilai nasabah dapat diterima untuk digunakan sebagai variabel independen dalam penelitian ini.

\section{Uji t Statistik}

Dari proses pengujian telah diperoleh hasil seperti terlihat pada Tabel sebagai berikut: 
Tabel 3

Hasil Pengujian Hipotesis

\begin{tabular}{|l|c|c|c|c|}
\hline \multicolumn{1}{|c|}{ Variabel Bebas } & t Tabel & t hitung & Sig. & Kesimpulan \\
\hline Bukti Fisik $\left(\mathrm{X}_{1}\right)$ & 1,985 & -0.762 & 0.448 & H1 Ditolak \\
\hline Empati $\left(\mathrm{X}_{2}\right)$ & 1,985 & -0.845 & 0.400 & H2 Ditolak \\
\hline Keandalan $\left(\mathrm{X}_{3}\right)$ & 1,985 & 1.596 & 0.114 & H3 Ditolak \\
\hline Daya Tanggap $\left(\mathrm{X}_{4}\right)$ & 1,985 & 1.192 & 0.236 & H4 Ditolak \\
\hline Jaminan $\left(\mathrm{X}_{5}\right)$ & 1,985 & -1.626 & 0.107 & H5 Ditolak \\
\hline Kepercayaan $\left(\mathrm{X}_{6}\right)$ & 1,985 & 2.326 & 0.022 & H6 Diterima \\
\hline Nilai Nasabah $\left(\mathrm{X}_{7}\right)$ & 1,985 & 7.406 & 0.000 & H7 Diterima \\
\hline
\end{tabular}

Sumber: Olahan Data SPSS 2017.

Dari hasil olahan data pengujian hipotesis yang dapat dilihat pada Tabel, diketahui bahwa:

Hipotesis 1: Hipotesis pertama dalam penelitian ini bahwa bukti fisik memiliki nilai signifikansi sebesar 0,448 , nilai signifikan tersebut lebih besar dari alpha 0,05. Hal ini dapat diartikan bahwa bukti fisik tidak berpengaruh terhadap kepuasan nasabah pada PT. Bank Mandiri (Persero) Padang Cabang Belakang Olo.

Hipotesis 2: Hipotesis kedua dalam penelitian ini bahwa empati memiliki nilai signifikansi sebesar 0,400, nilai signifikan tersebut lebih besar dari alpha 0,05. Hal ini dapat diartikan bahwa empati tidak berpengaruh terhadap kepuasan nasabah pada PT. Bank Mandiri (Persero) Padang Cabang Belakang Olo.

Hipotesis 3: Hipotesis ketiga dalam penelitian ini bahwa keandalan memiliki nilai signifikansi sebesar 0,114 , nilai signifikan tersebut lebih besar dari alpha 0,05. Hal ini dapat diartikan bahwa keandalan tidak berpengaruh terhadap kepuasan nasabah pada PT. Bank Mandiri (Persero) Padang Cabang Belakang Olo.

Hipotesis 4: Hipotesis keempat dalam penelitian ini bahwa daya tanggap memiliki nilai signifikansi sebesar 0,236 , nilai signifikan tersebut lebih besar dari alpha 0,05. Hal ini dapat diartikan bahwa daya tanggap tidak berpengaruh terhadap kepuasan nasabah pada PT. Bank Mandiri (Persero) Padang Cabang Belakang Olo.

Hipotesis 5: Hipotesis kelima dalam penelitian ini bahwa jaminan memiliki nilai signifikansi sebesar 0,107 , nilai signifikan tersebut lebih besar dari alpha 0,05. Hal ini dapat diartikan bahwa bukti fisik tidak berpengaruh terhadap kepuasan nasabah pada PT. Bank Mandiri (Persero) Padang Cabang Belakang Olo.

Hipotesis 6: Hipotesis keenam dalam penelitian ini bahwa kepercayaan memiliki nilai signifikansi sebesar 0,022, nilai signifikan tersebut lebih kecil dari alpha 0,05. Hal ini dapat diartikan bahwa kepercayaan berpengaruh positif dan signifikan terhadap kepuasan nasabah pada PT. Bank Mandiri (Persero) Padang Cabang belakang Olo.

Hipotesis 7: Hipotesis ketujuh dalam penelitian ini bahwa nilai nasabah memiliki nilai signifikansi sebesar 0,000, nilai signifikan tersebut lebih kecil dari alpha 0,05 . Hal ini dapat diartikan bahwa kepercayaan berpengaruh positif dan 
signifikan terhadap kepuasan nasabah pada PT. Bank Mandiri (Persero) Padang Cabang belakang Olo.

\section{Uji Koefisien Determinasi}

Dari proses pengujian koefisien determinasi yang telah dilakukan diperoleh ringkasan hasil seperti yang terlihat pada Tabel berikut ini:

Tabel 4

Hasil Pengujian Koefisien Determinasi

Model Sum mary ${ }^{\circ}$

\begin{tabular}{|l|r|r|r|r|r|}
\hline Model & $\mathrm{R}$ & R Square & Adjusted R Square & $\begin{array}{c}\text { Std. Error of the } \\
\text { Estimate }\end{array}$ & Durbin-Watson \\
\hline 1 & $.737^{2}$ & .544 & .509 & .534 & 1.442 \\
\hline
\end{tabular}

a. Predictors: (Constant), Nilai Nasabah, Daya Tanggap, Kepercayaan, Bukti Fisik, Keandalan, Empati,

Jaminan

b. Dependent Variable: Kepuasan

Nasabah

Sumber: Olahan Data SPSS 2017.

Dari hasil olahan data yang dapat dilihat pada Tabel, diketahui bahwa dari pengujian Koefisien Determinasi terlihat nilai Adjusted R square adalah sebesar 0,509 atau sama dengan 50,9\%. Hasil tersebut memperlihatkan bahwa kepuasan nasabah pada pada PT. Bank Mandiri (Persero) Padang Cabang belakang Olo yang dapat dijelaskan oleh bukti fisik, empati, keandalan, daya tanggap, jaminan, kepercayaan, dan nilai nasabah sebesar 50,9\%, sedangkan sisanya 49,1\% diduga dijelaskan oleh faktor-faktor lain yang tidak diteliti dalam penelitian ini, seperti citra bank, dan bauran pemasaran jasa.

\section{Pembahasan}

\section{Pengaruh Bukti Fisik Terhadap Kepuasan Nasabah}

Berdasarkan pada tabel yang telah disajikan untuk hipotesis pertama didapatkan hasil estimasi variabel bukti fisik memiliki nilai signifikansi 0,448 . Nilai signifikansi tersebut besar dari $\alpha=0,05$ yang menunjukkan bahwa variabel bukti fisik tidak berpengaruh terhadap kepuasan nasabah. Dengan demikian dapat disimpulkan bahwa tidak ada pengaruh bukti fisik terhadap kepuasan nasabah pada PT. Bank Mandiri (Persero) Padang Cabang Belakang Olo.

Kotler dan Keller (2009, 165) menjelaskan kepuasan pelanggan merupakan suatu kunci sukses untuk mendapatkan keuntungan dari pelanggan. Kepuasan yang dirasakan oleh pelanggan diperoleh dari kualitas produk dan kualitas layanan yang diberikan oleh perusahaan untuk memenuhi kebutuhan dan kepuasan pelanggan (Kotler dan Keller 2009, 169).

Penelitian ini tidak sejalan dengan penelitian yang dilakukan oleh Tran, dkk (2015) tentang service quality effects on customer satisfaction in banking industry. Penelitian ini menguji hubungan antara lima faktor dalam model kualitas pelayanan dan kepuasan pelanggan dengan layanan deposit VCBs. Menurut hasil penelitian, lima faktor yang positif terkait dengan kepuasan pelanggan. Namun, kehandalan yang hanya memiliki dukungan parsial, menunjukkan kebutuhan untuk meningkatkan keandalan pada deposit VCBs menjadi lebih kompetitif di pasar.

Ferry, dkk (2013) dalam penelitiannya tentang pengaruh kualitas layanan dan kepercayaan terhadap kepuasan Nasabah Kredit Mikro Pada Bank Pt. BTPN 
Argamakmur. Berdasarkan hasil penelitian ini, bahwa hubungan kepercayaan dan kepuasan nasabah pada Bank BTPN Cabang Argamakmur memiliki pengaruh yang cukup kuat terhadap penciptaan kepuasan nasabah atas bank. Dampak dari kepercayaan yang baik atas pelayanan dan aktivitas perbankan tentunya akan dapat membangun hubungan jangka panjang. Oleh karena hubungan yang terbangun antara pihak bank dan nasabah telah terjalin dengan baik dan dapat memberikan kepuasan kepada nasabah maka dalam jangka panjang pihak perbankan perlu mempertahankan dan berupaya untuk meningkatkan kepercayaan nasabah.

\section{Pengaruh Empati Terhadap Kepuasan Nasabah}

Berdasarkan pada tabel yang telah disajikan untuk hipotesis kedua didapatkan hasil estimasi variabel empati memiliki nilai signifikansi 0,400. Nilai signifikansi tersebut besar dari $\alpha=0,05$ yang menunjukkan bahwa variabel empati tidak berpengaruh terhadap kepuasan nasabah. Dengan demikian dapat disimpulkan bahwa tidak ada pengaruh empati terhadap kepuasan nasabah pada PT. Bank Mandiri (Persero) Padang Cabang Belakang Olo.

Rambat dan Ahmad (2009), kualitas pelayanan atau jasa, dimana pelanggan akan merasa puas bila mereka mendapatkan pelayanan yang baik atau sesuai dengan yang diharapkan. Kualitas jasa harus dimulai dari kebutuhan pelanggan dan berakhir dengan kepuasan pelanggan serta persepsi positif terhadap kualitas jasa (Fandy dan Gregorious, 2011:180).

Penelitian ini tidak sejalan dengan penelitian yang dilakukan oleh Tran, dkk (2015) tentang service quality effects on customer satisfaction in banking industry. Penelitian ini menguji hubungan antara lima faktor dalam model kualitas pelayanan dan kepuasan pelanggan dengan layanan deposit VCBs. Menurut hasil penelitian, lima faktor yang positif terkait dengan kepuasan pelanggan. Namun, kehandalan yang hanya memiliki dukungan parsial, menunjukkan kebutuhan untuk meningkatkan keandalan pada deposit VCBs menjadi lebih kompetitif di pasar.

Ferry, dkk (2013) dalam penelitiannya tentang pengaruh kualitas layanan dan kepercayaan terhadap kepuasan Nasabah Kredit Mikro Pada Bank Pt. BTPN Argamakmur. Berdasarkan hasil penelitian ini, bahwa hubungan kepercayaan dan kepuasan nasabah pada Bank BTPN Cabang Argamakmur memiliki pengaruh yang cukup kuat terhadap penciptaan kepuasan nasabah atas bank. Dampak dari kepercayaan yang baik atas pelayanan dan aktivitas perbankan tentunya akan dapat membangun hubungan jangka panjang. Oleh karena hubungan yang terbangun antara pihak bank dan nasabah telah terjalin dengan baik dan dapat memberikan kepuasan kepada nasabah maka dalam jangka panjang pihak perbankan perlu mempertahankan dan berupaya untuk meningkatkan kepercayaan nasabah.

\section{Pengaruh Keandalan Terhadap Kepuasan Nasabah}

Berdasarkan pada tabel yang telah disajikan untuk hipotesis ketiga didapatkan hasil estimasi variabel keandalan memiliki nilai signifikansi 0,114 . Nilai signifikansi tersebut besar dari $\alpha=0,05$ yang menunjukkan bahwa variabel keandalan tidak berpengaruh terhadap kepuasan nasabah. Dengan demikian dapat 
disimpulkan bahwa tidak ada pengaruh keandalan terhadap kepuasan nasabah pada PT. Bank Mandiri (Persero) Padang Cabang Belakang Olo.

Kotler dan Keller (2009, 165) menjelaskan kepuasan pelanggan merupakan suatu kunci sukses untuk mendapatkan keuntungan dari pelanggan. Kepuasan yang dirasakan oleh pelanggan diperoleh dari kualitas produk dan kualitas layanan yang diberikan oleh perusahaan untuk memenuhi kebutuhan dan kepuasan pelanggan (Kotler dan Keller 2009, 169).

Penelitian ini tidak sejalan dengan penelitian yang dilakukan oleh Tran, dkk (2015) tentang service quality effects on customer satisfaction in banking industry. Penelitian ini menguji hubungan antara lima faktor dalam model kualitas pelayanan dan kepuasan pelanggan dengan layanan deposit VCBs. Menurut hasil penelitian, lima faktor yang positif terkait dengan kepuasan pelanggan. Namun, kehandalan yang hanya memiliki dukungan parsial, menunjukkan kebutuhan untuk meningkatkan keandalan pada deposit VCBs menjadi lebih kompetitif di pasar.

Ferry, dkk (2013) dalam penelitiannya tentang pengaruh kualitas layanan dan kepercayaan terhadap kepuasan Nasabah Kredit Mikro Pada Bank Pt. BTPN Argamakmur. Berdasarkan hasil penelitian ini, bahwa hubungan kepercayaan dan kepuasan nasabah pada Bank BTPN Cabang Argamakmur memiliki pengaruh yang cukup kuat terhadap penciptaan kepuasan nasabah atas bank. Dampak dari kepercayaan yang baik atas pelayanan dan aktivitas perbankan tentunya akan dapat membangun hubungan jangka panjang. Oleh karena hubungan yang terbangun antara pihak bank dan nasabah telah terjalin dengan baik dan dapat memberikan kepuasan kepada nasabah maka dalam jangka panjang pihak perbankan perlu mempertahankan dan berupaya untuk meningkatkan kepercayaan nasabah.

\section{Pengaruh Daya Tanggap Terhadap Kepuasan Nasabah}

Berdasarkan pada tabel yang telah disajikan untuk hipotesis keempat didapatkan hasil estimasi variabel daya tanggap memiliki nilai signifikansi 0,236. Nilai signifikansi tersebut besar dari $\alpha=0,05$ yang menunjukkan bahwa variabel daya tanggap tidak berpengaruh terhadap kepuasan nasabah. Dengan demikian dapat disimpulkan bahwa tidak ada pengaruh daya tanggap terhadap kepuasan nasabah pada PT. Bank Mandiri (Persero) Padang Cabang Belakang Olo.

Rambat dan Ahmad (2009), kualitas pelayanan atau jasa, dimana pelanggan akan merasa puas bila mereka mendapatkan pelayanan yang baik atau sesuai dengan yang diharapkan. Kualitas jasa harus dimulai dari kebutuhan pelanggan dan berakhir dengan kepuasan pelanggan serta persepsi positif terhadap kualitas jasa (Fandy dan Gregorious, 2011:180).

Penelitian ini tidak sejalan dengan penelitian yang dilakukan oleh Tran, dkk (2015) tentang service quality effects on customer satisfaction in banking industry. Penelitian ini menguji hubungan antara lima faktor dalam model kualitas pelayanan dan kepuasan pelanggan dengan layanan deposit VCBs. Menurut hasil penelitian, lima faktor yang positif terkait dengan kepuasan pelanggan. Namun, kehandalan yang hanya memiliki dukungan parsial, menunjukkan kebutuhan untuk meningkatkan keandalan pada deposit VCBs menjadi lebih kompetitif di pasar. 
Ferry, dkk (2013) dalam penelitiannya tentang pengaruh kualitas layanan dan kepercayaan terhadap kepuasan Nasabah Kredit Mikro Pada Bank Pt. BTPN Argamakmur. Berdasarkan hasil penelitian ini, bahwa hubungan kepercayaan dan kepuasan nasabah pada Bank BTPN Cabang Argamakmur memiliki pengaruh yang cukup kuat terhadap penciptaan kepuasan nasabah atas bank. Dampak dari kepercayaan yang baik atas pelayanan dan aktivitas perbankan tentunya akan dapat membangun hubungan jangka panjang. Oleh karena hubungan yang terbangun antara pihak bank dan nasabah telah terjalin dengan baik dan dapat memberikan kepuasan kepada nasabah maka dalam jangka panjang pihak perbankan perlu mempertahankan dan berupaya untuk meningkatkan kepercayaan nasabah.

\section{Pengaruh Jaminan Terhadap Kepuasan Nasabah}

Berdasarkan pada tabel yang telah disajikan untuk hipotesis kelima didapatkan hasil estimasi variabel jaminan memiliki nilai signifikansi 0,107. Nilai signifikansi tersebut besar dari $\alpha=0,05$ yang menunjukkan bahwa variabel jaminan tidak berpengaruh terhadap kepuasan nasabah. Dengan demikian dapat disimpulkan bahwa tidak ada pengaruh jaminan terhadap kepuasan nasabah pada PT. Bank Mandiri (Persero) Padang Cabang Belakang Olo.

Kotler dan Keller (2009, 165) menjelaskan kepuasan pelanggan merupakan suatu kunci sukses untuk mendapatkan keuntungan dari pelanggan. Kepuasan yang dirasakan oleh pelanggan diperoleh dari kualitas produk dan kualitas layanan yang diberikan oleh perusahaan untuk memenuhi kebutuhan dan kepuasan pelanggan (Kotler dan Keller 2009, 169).

Penelitian ini tidak sejalan dengan penelitian yang dilakukan oleh Tran, dkk (2015) tentang service quality effects on customer satisfaction in banking industry. Penelitian ini menguji hubungan antara lima faktor dalam model kualitas pelayanan dan kepuasan pelanggan dengan layanan deposit VCBs. Menurut hasil penelitian, lima faktor yang positif terkait dengan kepuasan pelanggan. Namun, kehandalan yang hanya memiliki dukungan parsial, menunjukkan kebutuhan untuk meningkatkan keandalan pada deposit VCBs menjadi lebih kompetitif di pasar.

Ferry, dkk (2013) dalam penelitiannya tentang pengaruh kualitas layanan dan kepercayaan terhadap kepuasan Nasabah Kredit Mikro Pada Bank Pt. BTPN Argamakmur. Berdasarkan hasil penelitian ini, bahwa hubungan kepercayaan dan kepuasan nasabah pada Bank BTPN Cabang Argamakmur memiliki pengaruh yang cukup kuat terhadap penciptaan kepuasan nasabah atas bank. Dampak dari kepercayaan yang baik atas pelayanan dan aktivitas perbankan tentunya akan dapat membangun hubungan jangka panjang. Oleh karena hubungan yang terbangun antara pihak bank dan nasabah telah terjalin dengan baik dan dapat memberikan kepuasan kepada nasabah maka dalam jangka panjang pihak perbankan perlu mempertahankan dan berupaya untuk meningkatkan kepercayaan nasabah. 


\section{Pengaruh Kepercayaan Terhadap Kepuasan Nasabah}

Berdasarkan pada tabel yang telah disajikan untuk hipotesis keenam didapatkan hasil estimasi variabel kepercayaan memiliki nilai signifikansi 0,022. Nilai signifikansi tersebut kecil dari $\alpha=0,05$ yang menunjukkan bahwa variabel kepercayaan berpengaruh positif dan signifikan terhadap kepuasan nasabah. Dengan demikian dapat disimpulkan bahwa ada pengaruh kepercayaan terhadap kepuasan nasabah pada PT. Bank Mandiri (Persero) Padang Cabang Belakang Olo.

Kepercayaan konsumen menurut Mowen dan Minor (2002:312) adalah semua pengetahuan yang dimiliki oleh konsumen dan semua kesimpulan yang dibuat konsumen tentang objek, atribut, dan manfaatnya. Kepercayaan adalah keyakinan bahwa seseorang akan menemukan apa yang diinginkan pada mitra pertukaran. Kepercayaan melibatkan kesediaan seseorang untuk bertingkah laku tertentu karena keyakinan bahwa mitranya akan memberikan apa yang ia harapkan dan suatu harapan yang umumnya dimiliki seseorang bahwa kata, janji atau pernyataan orang lain dapat dipercaya (Barnes, 2003:148).

Menurut Peppers dan Rogers (2004:43), kepercayaan adalah keyakinan satu pihak pada reliabilitas, durabilitas, dan integritas pihak lain dalam relationship dan keyakinan bahwa tindakannya merupakan kepentingan yang paling baik dan akan menghasilkan hasil positif bagi pihak yang dipercaya. Dari definisi-definisi diatas, kepercayaan dapat disimpulkan sebagai suatu perasaan untuk yakin terhadap pihak lain maupun terhadap suatu hubungan.

Hasil penelitian ini sejalan dengan penelitian yang dilakukan oleh Rachmad Hidayat (2009). Berdasarkan analisis studi dan pembahasan yang telah dibuktikan baik secara kualitatif maupun kuantitatif dapat disusun kesimpulan sebagai berikut: kualitas layanan berpengaruh positif dan signifikan terhadap kepuasan nasabah dan nilai bagi nasabah berpengaruh positif dan signifikan terhadap kepuasan nasabah.

Penelitian lain yang dilakukan oleh Moch Syaepul Mukarom dan Imroatul Khasanah (2012). Berdasarkan hasil pengujian hipootesis secara parsial dapat disimpulkan bahwa melalui pengujian hipotesis, nilai nasabah terbukti berpengaruh positif dan signifikan terhadap kepuasan nasabah nasabah BRI. Selanjutnya pengujian hipotesis kualitas pelayanan terbukti berpengaruh positif dan signifikan terhadap kepuasan nasabah BRI.

Penelitian Ahmad Guspula. (2014), berdasarkan hasil penelitian diketahui bahwa kulitas pelayanan yang dilihat dari 5 dimensi: tangibles, reliability, responsiveness, assurance dan empathy dan variabel kepercayaan mempunyai pengaruh yang signifikan terhadap kepuasan nasabah jasa keuangan Kospin jasa cabang Wonosobo.

Penelitian yang dilakukan oleh Ferry Albizar, dkk (2013), Dimana hasil penelitian menemukan bahwa terdapat pengaruh yang signifikan dan positif antara kualitas pelayanan dan kepercayaan terhadap kepuasan nasabah pada Bank BTPN Cabang Argamakmur Bengkulu.

\section{Pengaruh Nilai Nasabah Terhadap Kepuasan Nasabah}

Berdasarkan pada tabel yang telah disajikan untuk hipotesis ketujuh didapatkan hasil estimasi variabel nilai nasabah memiliki nilai signifikansi 0,000. 
Nilai signifikansi tersebut kecil dari $\alpha=0,05$ yang menunjukkan bahwa variabel nilai nasabah berpengaruh positif dan signifikan terhadap kepuasan nasabah. Dengan demikian dapat disimpulkan bahwa ada pengaruh kepercayaan terhadap kepuasan nasabah pada PT. Bank Mandiri (Persero) Padang Cabang Belakang Olo.

Satu-satunya nilai yang dapat diciptakan perusahaan adalah nilai yang berasal dari pelanggan, itu adalah semua nilai yang dimiliki sekarang dan nilai yang dimiliki dimasa depan. Suatu bisnis disebut sukses jika berhasil mendapatkan, mempertahankan, dan membutuhkan pelanggan (Kotler dan Keller, 2009: 134). Menurut Kotler dan Amstrong (2008), nilai bagi pelanggan merupakan perbedaan antara nilai yang dinikmati pelanggan karena memiliki serta menggunakan suatu produk dan biaya untuk memiliki produk tersebut.

Hasil penelitian ini sejalan dengan penelitian yang dilakukan oleh Rachmad Hidayat (2009). Berdasarkan analisis studi dan pembahasan yang telah dibuktikan baik secara kualitatif maupun kuantitatif dapat disusun kesimpulan sebagai berikut: kualitas layanan berpengaruh positif dan signifikan terhadap kepuasan nasabah dan nilai bagi nasabah berpengaruh positif dan signifikan terhadap kepuasan nasabah.

Penelitian lain yang dilakukan oleh Moch Syaepul Mukarom dan Imroatul Khasanah (2012). Berdasarkan hasil pengujian hipootesis secara parsial dapat disimpulkan bahwa melalui pengujian hipotesis, nilai nasabah terbukti berpengaruh positif dan signifikan terhadap kepuasan nasabah nasabah BRI. Selanjutnya pengujian hipotesis kualitas pelayanan terbukti berpengaruh positif dan signifikan terhadap kepuasan nasabah BRI.

Penelitian Ahmad Guspula. (2014), berdasarkan hasil penelitian diketahui bahwa kulitas pelayanan yang dilihat dari 5 dimensi: tangibles, reliability, responsiveness, assurance dan empathy dan variabel kepercayaan mempunyai pengaruh yang signifikan terhadap kepuasan nasabah jasa keuangan Kospin jasa cabang Wonosobo.

Penelitian yang dilakukan oleh Ferry Albizar, dkk (2013), Dimana hasil penelitian menemukan bahwa terdapat pengaruh yang signifikan dan positif antara kualitas pelayanan dan kepercayaan terhadap kepuasan nasabah pada Bank BTPN Cabang Argamakmur Bengkulu.

\section{SIMPULAN}

1. Bukti fisik tidak berpengaruh terhadap kepuasan nasabah pada PT. Bank Mandiri (Persero) Tbk. Padang Cabang Olo. Bukti fisik memiliki nilai signifikansi sebesar 0,448 , nilai signifikan tersebut lebih besar dari alpha 0,05 .

2. Empati tidak berpengaruh terhadap kepuasan nasabah pada PT. Bank Mandiri (Persero) Tbk. Padang Cabang Olo. Empati memiliki nilai signifikansi sebesar 0,400, nilai signifikan tersebut lebih besar dari alpha 0,05.

3. Keandalan tidak berpengaruh terhadap kepuasan nasabah pada PT. Bank Mandiri (Persero) Tbk. Padang Cabang Olo. Keandalan memiliki nilai signifikansi sebesar 0,114 , nilai signifikan tersebut lebih besar dari alpha 0,05 . 
4. Daya Tanggap tidak berpengaruh terhadap kepuasan nasabah pada PT. Bank Mandiri (Persero) Tbk. Padang Cabang Olo. Daya tanggap memiliki nilai signifikansi sebesar 0,236 , nilai signifikan tersebut lebih besar dari alpha 0,05 .

5. Jaminan tidak berpengaruh terhadap kepuasan nasabah pada PT. Bank Mandiri (Persero) Tbk. Padang Cabang Olo. Jaminan memiliki nilai signifikansi sebesar 0,107 , nilai signifikan tersebut lebih besar dari alpha 0,05 .

6. Kepercayaan berpengaruh signifikan terhadap kepuasan nasabah pada PT. Bank Mandiri (Persero) Tbk. Padang Cabang Olo. Kepercayaan memiliki nilai signifikansi sebesar 0,022 , nilai signifikan tersebut lebih kecil dari alpha 0,05 .

7. Nilai Nasabah berpengaruh signifikan terhadap kepuasan nasabah pada PT. Bank Mandiri (Persero) Tbk. Padang Cabang Olo. Kepercayaan memiliki nilai signifikansi sebesar 0,000 , nilai signifikan tersebut lebih kecil dari alpha 0,05 .

8. Dari hasil olahan data diketahui bahwa dari pengujian Koefisien Determinasi terlihat nilai Adjusted $\mathrm{R}$ square adalah sebesar 0,509 atau sama dengan 50,9\%. Hasil tersebut memperlihatkan bahwa kepuasan nasabah pada pada PT. Bank Mandiri (Persero) Padang Cabang belakang Olo yang dapat dijelaskan oleh bukti fisik, empati, keandalan, daya tanggap, jaminan, kepercayaan, dan nilai nasabah sebesar 50,9\%, sedangkan sisanya 49,1\% diduga dijelaskan oleh faktor-faktor lain yang tidak diteliti dalam penelitian ini, seperti citra bank, dan bauran pemasaran jasa.

\section{DAFTAR PUSTAKA}

Aziz, N. (2019). Pengaruh Kualitas Layanan Terhadap Kepuasan Nasabah SMS Banking Pada Bank Nagari Cabang Pembantu RSUP DR M Djamil Padang. https://doi.org/10.17605/OSF.IO/S3JVG

Barnes, 2003. Elemen Kepercayaan.(http:// barnes.blogspot.com / 2011 /04 /elemen kepercayaan. Html). Diakes 12 april 2012

Bramson, Robert. 2005. “Costumer loyalty 50”. Jakarta : Rineka Cipta.

Cronin., Brady, 2001. "Service Quality”. Online

Fandy Tjiptono. 2008." Service Management Mewujudkan Layanan Prima". Yogyakarta. Andy offset.

Farida Jasfar. 2009. Manajemen Jasa Pendekatan Terpadu. Jakarta: Ghalia Indonesia 
Fernandes, Y. D., \& Marlius, D. (2018). Peranan Customer Service Dalam Meningkatkan Pelayanan Kepada Nasabah Pada PT. Bank Pembangunan Daerah Sumatera Barat Cabang Utama Padang. https://oi.org/10.31227/osf.io/wrh3p

Fernos, J., \& Putra, Y. E. (2019). Analisa Pengaruh Kualitas Pelayanan Terhadap Kepuasan Nasabah Pada PT. Bank Mega Syari'ah Padang. https://oi.org/10.31219/osf.io/y2baf

Flavian dan Giunaliu. 2007. Measure On Web Usability Website. Journal of Computer Information Systems 48 (no. 1) hal 17-23

Kasmir. 2004. Bank dan lembaga keuangan lainnya. Jakarta: PT. Raja Grafindo

Kotler, Philip,dkk.2000."Manajemen Pemasaran : Analisis, Perencanaan, Implimentasi, Dan Pengendalian”. Jakarta: Salemba Empat

Kotler, Philip.2001. Manajemen Pemasaran : Analisis, Perencanaan Implementasi, Dan Control. Jakarta : PT. Prehallindo

Kotler dan Keller. 2009. Manajemen Pemasaran. Jilid I Edisi ke 13 Jakarta : Erlangga.

Lupiyoadi, Rambat dan A. Hamdani 2001. "Manajemen Pemasaran Dan Jasa”. Jakarta : Salemba Empat

Marlius, D. (2018). Loyalitas Nasabah Bank Nagari Syariah Cabang Bukittinggi Dilihat Dari Kualitas Pelayanan. Jurnal Pundi. Volume 1. No. 3. Hal.1222. https://doi.org/10.31575/jp.v1i3.60

Marlius, D. (2018). Pengaruh Dimensi Kualitas Pelayanan Website Akademik Terhadap Kepuasan Mahasiswa Pada STIE 'KBP”. Jurnal Ipteks Terapan. Volume $12 . \quad$ No. $2 . \quad$ Hal. 116-128. http://doi.org/10.22216/jit.2018.v12i2.633

Nasution, M.N. 2010. Manajemen Jasa Terpadu. Bogor : Ghalia Indonesia

Nugroho, Bhuono Agung. 2005. "Strategi Jitu Memilih Metode Statistic Penelitian Dengan SPSS. Yogyakarta : Andi

Pappers and Rogen. 2004. Faktor-faktor Terbentuknya Kepercayaan.

Putra, Y. E., \& Aziz, N. (2019). Pengaruh Kualitas Pelayanan Dan Kepuasan Pelanggan Terhadap Loyalitas Nasabah PT. Bank Rakyat Indonesia Cabang Padang. https://doi.org/10.31219/osf.io/hcsw2 
Rambat, Lupiyoadi. 2008. Manajemen Pemasaran. Jakarta : Salemba Empat

Safitri, R. N., \& Marlius, D. (2017). Penerapan E-Banking Dalam Meningkatkan Jasa Dan Layanan Perbankan Di PT. Bank Rakyat Indonesia Cabang Padang. https://doi.org/10.31227/osf.io/gkv8t

Sarwono, Jonathan. 2009. Panduan Lengkap Untuk Belajar Komputasi Statistic Mengunakan SPSS 16. Yogyakarta : CV. Andi Offset

Susanti, F. \& W Ekazaputri. (2018). Service Performance Dan Kepuasan Sebagai Moderating Variabel Terhadap Loyalitas Nasabah Pada PT BPR Labuh Gunung Payakumbuh Jurnal Benefita: Ekonomi Pembangunan Manajemen Bisnis Dan Akuntansi. Volume 3. No. 3. Hal. 433444.http://doi.org/10.22216/jbe.v3i3.3472

Tiza, M. F., \& Susanti, F. (2019). Pengaruh Kualitas Pelayanan Terhadap Kepuasan Pelanggan, Studi kasus pada perusahaan JNE Cabang Padang. https://doi.org/10.31227/osf.io/hx87m

Ulfa, M., \& Mayliza, R. (2019). Pengaruh Kualitas Pelayanan Dan Kepuasan Pelanggan Terhadap Loyalitas Pelanggan PDAM Kota Padang. https://doi.org/10.31219/osf.io/spmgv

Winarsih, 2008. “Prisip-Prinsip Kualitas Pelayanan”. Jakarta

Zulian yamit. 2002. Manajemen Kualitas Produk Dan Jasa. Yogyakarta : Ekonisia 